\title{
Capecitabine as Second-Line Treatment for Metastatic Cholangiocarcinoma: A Report of Two Cases
}

\author{
J. Stemmler V. Heinemann A. Schalhorn
}

Abteilung für Innere Medizin III, Universitätsklinik München

\section{Key Words}

Capecitabine - Metastatic cholangiocarcinoma . Chemotherapy

\section{Summary}

Background: The management of recurrent, metastatic cholangiocarcinoma still remains a problem since this tumor entity is classified as chemotherapy-resistant. When advanced or metastatic disease is diagnosed, the therapeutic efforts are essentially directed toward palliation. Patients and Methods: We report on 2 patients suffering from metastatic cholangiocarcinoma. Both had received previous chemotherapy for metastatic disease, including hepatic artery infusion [5-fluorouracil (5-FU) / folinic acid (FA) and oxaliplatin] and a combination therapy consisting of 5-FU/FA and gemcitabine. Since a progression of the disease was diagnosed, both patients were started on oral capecitabine at a daily dose of $2,500 \mathrm{mg} / \mathrm{m}^{2}$ in 2 divided doses for 2 weeks, followed by 1 week rest. Results: Capecitabine was tolerated well and severe side effects were not observed. A stop of progression, documented by imaging procedures and tumor marker kinetics, was achieved in both patients. Conclusion: Capecitabine could potentially be used for secondline treatment in patients with progressive metastatic cholangiocarcinoma.

\section{Introduction}

With an incidence of 2-3/100,000/year in Europe, cholangiocarcinoma is one of the minor frequent cancer entities. Unresectable and metastatic cholangiocarcinoma has a dismal prognosis, and the 5-year survival rate is generally less than

\author{
Schlüsselwörter \\ Capecitabin - Metastasiertes cholangiozelluläres \\ Karzinom - Chemotherapie
}

\section{Zusammenfassung}

Hintergrund: Die Behandlung des metastasierten cholangiozellulären Karzinoms ist nach wie vor unbefriedigend, da dieser Tumor im allgemeinen als chemotherapieresistent eingestuft wird. In den fortgeschrittenen Stadien richten sich die therapeutischen Bemühungen daher auf die Palliation. Patienten und Methoden: Wir berichten über 2 Patienten mit hepatisch metastasiertem cholangiozellulärem Karzinom. Beide hatten bereits eine Chemotherapie im metastasierten Stadium erhalten [lokale, intraarterielle Chemotherapie mit 5-Fluorouracil (5-FU) / Folinsäure (FA) und Oxaliplatin bzw. systemisch 5-FU/FA und Gemcitabin]. Nachdem die Erkrankung im Verlauf progredient war, wurde eine orale Therapie mit Capecitabin eingeleitet $\left(2500 \mathrm{mg} / \mathrm{m}^{2}\right.$ täglich, verteilt auf 2 Dosen über 14 Tage). Ergebnisse: Capecitabin wurde ohne schwerwiegende Nebenwirkungen von beiden Patienten gut toleriert. Wie in den bildgebenden Verfahren als auch anhand der Tumormarkerverläufe dokumentiert, konnte durch die Therapie eine weitere Progression des Tumorleidens verhindert und eine klinische Stabilisierung erreicht werden. Schlussfolgerung: Capecitabin kann zur Second-Line-Therapie bei Patienten mit progredientem, metastasiertem cholangiozellulärem Karzinom erwogen werden.

$5 \%$ [1]. In the early stage of the disease, when a curative resection is possible, there are few or no symptoms. Symptoms occur at a late stage, so most patients are unresectable at diagnosis [1].

Therapeutic efforts at the metastatic stage are essentially directed toward palliation. Neither single drugs nor the mostly

\begin{tabular}{ll}
\hline KARGER & ( ) 2002 S. Karger GmbH, Freiburg \\
$\begin{array}{l}\text { Fax }+497614520714 \\
\begin{array}{l}\text { E-mail Information@Karger.de } \\
\text { www.karger.com }\end{array}\end{array}$ & Accessible online at: \\
www.karger.com/journals/onk
\end{tabular}


5-fluorouracil(5-FU)-based combination regimens, with response rates of $25-30 \%$, achieved a clinically meaningful prolongation of survival [1].

Capecitabine is a new, orally administrable fluoropyrimidine carbamate. After oral application the drug passes intactly through the intestinal mucosa and is first metabolized in the liver. The further catalytic activation to 5-FU occurs at the tumor site by the tumor-associated thymidine phosphorylase, thereby minimizing the exposure of healthy body tissues to systemic 5-FU [2-5]. The activity of the thymidine phosphorylase in liver metastases is statistically higher as in normal tissue [2-5]. Human pharmacokinetic studies have shown that the drug is well absorbed and rapidly converted to nontoxic intermediates [2-5]. As shown in preclinical and clinical studies, capecitabine was highly active against several solid tumors, and in both 5-FU-sensitive and 5-FU-resistant tumors [2-6]. In a pilot study of oral capecitabine for hepatobiliary cancers, the remission rate amounts to $16 \%$ [6].

The intermittent regimen is generally recommended, meaning the daily administration of $2,500 \mathrm{mg} / \mathrm{m}^{2}$ divided in 2 doses for 2 weeks, followed by 1 week without treatment $[7,8]$.

\section{Case Reports}

\section{Methods}

Patients were treated with capecitabine at a daily dose of $2,500 \mathrm{mg} / \mathrm{m}^{2}$ given orally divided in 2 doses over a period of 14 days, followed by one week rest. No premedication was given routinely. Tumor marker kinetics (CA19-9) were measured before the beginning of every new treatment cycle, and imaging procedures (ultrasound) were performed after every 2 cycles.

Case 1

A 47-year-old female was diagnosed with locally advanced cholangiocarcinoma in December 1999 (T3 N2 M0 G2-3). The patient was started on a neoadjuvant, locoregional therapy (hepatic artery infusion, HAI) consisting of mitoxantrone, 5-FU / folinic acid (FA) and cisplatin (12/1999 1/2000). After 2 cycles the tumor was surgically removed (histopathological staging: pT3 pN2(6/16) G2-3 R1). In February 2000, liver metastases were diagnosed. Due to limitation of the disease to the liver, locoregional therapy was continued (5-FU/FA/oxaliplatin). After 4 cycles, a partial remission was achieved and CA19-9 levels had decreased significantly (CA19-9 2/2000: 29,000 U/ml; 7/2000: $796 \mathrm{U} / \mathrm{ml}$ ). HAI was continued by omitting oxaliplatin due to grade 3 neuropathy. After 4 additional cycles, CA19-9 levels had decreased continuously to a minimum value of $42 \mathrm{U} / \mathrm{ml}$ (December 2000). Since rising CA19-9 levels and a progression of the hepatic metastasis were diagnosed in February 2001, the patient was started on oral capecitabine, which was tolerated well $(3,500 \mathrm{mg}$ orally per day, given in 2 divided doses).

Until now, the patient has received 6 cycles of capecitabine, which were tolerated well. Imaging procedures and CA19-9 values documented a stop of progression and a stabilization of the disease.

Case 2

A 71-year-old male was diagnosed with metastatic cholangiocarcinoma in December 2000. Systemic combination chemotherapy, consisting of gemcitabine and 5-FU/FA, was begun. As documented by CT scan after 3 treatment cycles, a clinical stabilization of the disease was achieved.
Therapy was continued until May 2001 when progression of liver metastasis was diagnosed. The patient was started on capecitabine $(4,500 \mathrm{mg}$ orally per day, given in 2 divided doses) which was tolerated without severe side effects.

Until now, the patient has received 4 cycles of capecitabine. Except for mild hand-foot syndrome after the 3 rd cycle, capecitabine was tolerated well. Imaging procedures and CA19-9 values demonstrated a clinical stabilization of the disease.

\section{Discussion}

With an incidence of 2-3/100,000/year in Europe, cholangiocarcinoma is one of the minor frequent cancer entities [1]. The higher stages as unresectable or metastatic cholangiocarcinoma have a dismal prognosis, with a 5-year survival rate of, generally, less than 5\% [1]. Therapeutic efforts at the advanced or metastatic stages are therefore essentially directed toward palliation. Neither single drugs nor the mostly 5-FU-based combination regimens achieved a clinically meaningful prolongation of survival, so current chemotherapeutic options are unsatisfactory [1].

New approaches to improve the response to chemotherapy have been the introduction of new drugs (gemcitabine/oxaliplatin/irinotecan) or locoregional treatment (hepatic artery infusion, HAI) which was associated with the highest response rates $[9,10]$. Both approaches have not been evaluated extensively so far, and a prolongation in survival has not been shown yet.

Capecitabine ( $\mathrm{N}^{4}$-pentoxycarbonyl-5'-deoxy-5-fluorocytidine, Xeloda; Hoffman-La Roche AG, Grenzach-Wyhlen, Germany) is a novel, orally administrable fluoropyrimidine carbamate which is selectively tumor-activated to 5-FU by exploiting the higher levels of thymidine phosphorylase found in tumor tissues compared with normal tissues [2-5]. The drug provides patients with an opportunity to undergo oral, outpatient fluoropyrimidine therapy.

Phase I trials have examined capecitabine either alone in continuous and intermittent regimens or combined with FA in an intermittent regimen. Phase II trials, in patients with metastatic colorectal cancer (CRC), have shown that none of the three mentioned regimens was markedly superior in terms of induction of durable objective responses. The intermittent regimen (2,500 $\mathrm{mg} / \mathrm{m}^{2} /$ day, orally twice daily, days $1-14$ and 7 days rest) is thereby similar in concept and design to the continuous infusion regimens of 5-FU tested and was found to be promising in studies conducted by the NCIC and Southwest Oncology Group [8].

The toxicity profile and the most frequent adverse events (grade 3 and 4, NCI-CTC) involved the gastrointestinal tract (diarrhea ca. 13\%, nausea and vomiting) and the integument (hand-foot syndrome ca. 9\%). Consistent with the dose-limiting toxicity of 5-FU as continuous infusion, capecitabine is dose-limited by diarrhea and the hand-foot syndrome [11-15]. In a randomized phase III trial in patients with metastatic $\mathrm{CRC}$, the overall response rate amounted to $25.7 \%$, which 
was statistically significantly superior to 5-FU/FA therapy $(\mathrm{p}<0.0002)[12,14]$. Even in 5-FU-adjuvant pretreated patients there was a significantly better response to capecitabine as compared to 5-FU (21 vs 9\%), while time to progression and survival were comparable in both groups. In the group of patients treated with capecitabine, there was a statistically significant lower incidence of grade 3 and 4 toxicities compared with the 5-FU-treated group $[12,14]$. In a pilot study of oral capecitabine for hepatobiliary cancers, the overall remission rate amounted to $16 \%$ and the most common toxicity was the hand-and-foot syndrome (37\%). The study has shown that capecitabine can be safely given to patients with hepatobiliary cancers, even to patients with liver cirrhosis [6].

In our reported patients, both of whom had been pretreated, we did not observe any grade 3 or grade 4 toxicity. All administered cycles were tolerated well, except for mild hand-foot syndrome after the 3 rd cycle in 1 patient. Despite pretreatment with a 5-FU-based regimen, stabilization of the disease was achieved in both patients. In conclusion, capecitabine could potentially be used for the treatment of metastatic cholangiocarcinoma. Further studies are necessary to evaluate the role of capecitabine as a single agent or in combination in the management of recurrent, metastatic cholangiocarcinoma.

\section{References}

1 DeVita VT Jr, Hellman S, Rosenberg SA: Cancer. Principles and Practice of Oncology, ed 6. Lippincott / Williams \& Wilkins, Philadelphia/Baltimore, 1999.

2 Van Cutsem E, Findlay M, Osterwalder B, Kocha W, Dalley D, Pazdur R, Cassidy J, Dirix L, Twelves C, Allman D, Seitz JF, Scholmerich J, Burger HU, Verweij J: Capecitabine, an oral fluoropyrimidine carbamate with substantial activity in advanced colorectal cancer: Results of a randomized phase II study. J Clin Oncol 2000;18:1337-1345.

3 Frings S: Capecitabine - a novel oral tumor-activated fluoropyrimidine. Onkologie 1998;21:451-458.

4 Schüller J, Cassidy J, Dumont E, Roos B, Durston S, Banken L, Utoh M, Mori K, Weidekamm E, Reigner B: Preferential activation of Capecitabine in tumor following oral administration to colorectal cancer patients. Cancer Chemother Pharmacol 2000;45:291-297.

5 Miwa M, Ura M, Nishida M, Sawada M, Ishikawa T, Mori K, Shimma M, Umeda I, Ishitsuka H: Design of a novel oral fluoropyrimidine carbamate, capacitabine, which generates 5 -fluorouracil selectively in tumors by enzymes concentrated in human liver and cancer tissue. Eur J Cancer 1998;34: 1274-1281.

6 Lozano RD, Patt YZ, Hassan MM, Frome A, Vauthey JN, Ellis LM, Schnirer I, Brown TD, Abbruzzese JL, Wolff RA, Charnsangavej C: Oral capecitabine (Xeloda) for the treatment of hepatobiliary cancers (hepatocellular carcinoma, cholangiocarcinoma and gallbladder cancer). Proc Am Soc Clin Oncol 2000;19:1025(abstract).

7 Cassidy J, Dirix L, Bissett D, Reigner B, Griffin T, Allman, Osterwalder B, Van Oosterom AT: A phase I study of Capecitabine in combination with oral leucovorin in patients with intractable solid tumors. Clin Can Res 1998;4:2755-2761.

8 Mackean MJ, Planting ASTh, Twelves C, Schellens JHM, Allman D, Osterwalder B, Reigner B, Griffin T, Kaye S, Verweij J: A phase I and pharmacologic study of intermittent twice daily oral therapy with Capecitabine in patients with advanced and/or metastatic cancer. J Clin Oncol 1998;16:2977-2985.
9 Verderame F, Mandina P, Abruzzo F, Scarpula M, DiLeo R: Biliary tract cancer: Our experience with gemcitabine treatment. Anticancer Drugs 2000;11: 707-708.

10 Todoroki T: Chemotherapy for bile duct carcinoma in the light of adjuvant chemotherapy to surgery. Hepatogastroenterology 2000;47:644-649.

11 Blum JL, Jones SE, Buzdar AU, LoRusso PM, Kuter I, Vogel C, Osterwalder B, Burger HU, Brown CS, Griffin T: A multicenter phase II study of Capecitabine in paclitaxel-refractory metastatic breast cancer. J Clin Oncol 1999;17:485-493.

12 O'Shaughnessy JA, Blum J, Moiseyenko V, Jones SE, Miles D, Bell D, Rosso R, Mauriac L, Osterwalder B, Burger HU, Laws S: Randomized, openlabel, phase II trial of oral capecitabine $\left(\mathrm{Xeloda}^{\circledR}\right)$ vs. a reference arm of intravenous CMF (cyclophosphamide, methotrexate and 5-fluorouracil) as first-line therapy for advanced/metastatic breast cancer. Ann Oncol 2001;12:1247-1254.

13 Blum JL: Xeloda ${ }^{\circledR}$ in the treatment of metastatic breast cancer. Oncology 1999;57(suppl 1):16-20.

14 Hoff PM, Ansari R, Batist G, Cox J, Kocha W, Kuperminc M, Maroun J, Walde D, Weaver C, Harrison $\mathrm{E}$, Burger $\mathrm{HU}$, Osterwalder $\mathrm{B}$, Wong $\mathrm{AO}$, Wong R: Comparison of oral capecitabine versus intravenous fluorouracil plus leucovorin as firstline treatment in 605 patients with metastatic colorectal cancer: Results of a randomized phase III study. J Clin Oncol 2001;19:2282-2292.

15 Van Cutsem E, Twelves C, Cassidy J, Allman D, Bajetta E, Boyer M, Bugat R, Findlay M, Frings S, Jahn M, McKendrick J, Osterwalder B, PerezManga G, Rosso R, Rougier P, Schmiegel WH, Seitz JF, Thompson P, Vieitez JM, Weitzel C, Harper P: Oral capecitabine compared with intravenous fluorouracil plus leucovorin in patients with metastatic colorectal cancer: Results of a large phase III study. J Clin Oncol 2001;19:4097-4106. 